\title{
Metascientific language and the changing identities of modern science
}

\author{
Désirée Schauz: Nützlichkeit und Erkenntnisfortschritt. Eine \\ Geschichte des modernen Wissenschaftsverständnisses. Göttingen: \\ Wallstein Verlag, 2020, 39,00€ HB
}

\section{Phillip H. Roth ${ }^{1}$}

Accepted: 24 August 2021 / Published online: 28 August 2021

(c) The Author(s) 2021

In her book Nützlichkeit und Erkenntnisfortschritt, Désirée Schauz provides us with a longue durée history of the changing understandings of modern natural science, focusing on Germany. But her work goes beyond a mere history of ideas, looking instead at overarching scientific categories and crucial semantic innovations, and placing them in the wider socio-historical context of German science, politics, and society.

Schauz's book is the most recent installment in a compelling history and sociology of science and technology that has brought to light the subjectivity of the conceptual foundations on which our understanding of and communication about science rest. Drawing on the conceptual history (Begriffsgeschichte) approach pioneered by German historian Reinhart Koselleck, these scholars have fundamentally questioned the assumption that basic concepts like pure science, technology, or basic and applied research act as neutral categories. Instead, they have studied them as expressions of specific historical experiences in relation to expectations and desires in the context of changing social and political circumstances. These studies show us that key terms on which we depend so naturally-without reflecting on their ambiguity and semantic history-were in fact hotly contested and the product of historical contingency.

Accordingly, the investigation in Nützlichkeit und Erkenntnisfortschritt revolves around key concepts in science policy discourses ("wissenschaftspolitische Schlüsselbegriffe") and their histories. Science policy here is taken in broad terms, since the understandings of natural science are not only negotiated among scientists themselves, but between many different actors in society. Looking at fundamental concepts in the science policy discourses gives Schauz access to the metascientific

Phillip H. Roth

phillip.roth@khk.rwth-aachen.de

1 Käte Hamburger Kolleg: Cultures of Research, RWTH Aachen University, Aachen, Germany 
debates in which the formative negotiation and demarcation processes of German natural science took place. A central premise of the book is that scientific identity, as a professional self-image ("im Sinne eines professionellen Selbstverständnisses") with specific values and motives, is constructed in discussions over social attributions ("Zuschreibungen") and expectations of science (22). In discursive practices of what Schauz and others call "identity work," researchers over the centuries balanced their professional autonomy with the expectations and values of actors in society in order to sustain their scientific pursuits. In the process, they have continually redefined the utility, the practices and contents of science, and ultimately the enterprise itself.

Schauz's book has six chapters. The first lays out her research program and connects her investigation to a wide range of current debates in the History and Sociology of Science and in STS. The following four chapters are each devoted to significant transitions in the identity of science between the seventeenth century and the very recent past. All is topped off in the sixth and final chapter with a résumé of central findings.

As laid out in Chapter One, the investigation is guided by three main aims. First, Schauz sees the need to better assess the extents to which the scientific system has undergone a structural transition by identifying changes of and constants in the idea of science. This is occasioned by the new vocabulary adopted by many scholars in STS, Sociology and the History of Science, with terms like technoscience signaling a radical transformation away from the ideal of pure or basic science, as well as by newer research policy objectives for technological innovation. She takes these real and perceived changes as an occasion to put into historical perspective per se our conceptions of natural science and the ideas about the purposes it should serve.

Second, historicizing the understanding of science will contribute to the semantic reflexivity of science studies in general and STS in particular (29). Schauz presents her work as something that transcends popular approaches in the field, which, in one way or another, share a skepticism about the ideal of pure science. Deconstructing only the pure science ideal is one-sided, she maintains. We need to similarly question the currently prevailing ideal of applicability and therefore approach the modern scientific understanding ("das neuzeitliche Wissenschaftsverständnis") through the symmetry of its ideals of utility and truth (27).

Finally, the genuinely historical aim of her study is to provide a corrective for the selective and often distorting historical references consulted in current debates. However, it is of great merit that the implications of Schauz's work go beyond historiographical interests and regard revealing the historical contingency of current views of science as a crucial historiographic contribution to the study of science, technology, and society ("Wissenschafts- und Technikforschung") (36).

It is telling that the second Chapter begins with the metascientific ideas of Francis Bacon. Although a British scholar, Bacon's thoughts were essential also for forming German discourses on science in the early modern period. And while Schauz's overall focus is on Germany, she is very sensitive throughout to how foreign ideas and discourses have influenced German understandings of science as well as to the parallel developments in other European countries and the USA. Bacon today features as a central reference point in the debates about technoscience. But Schauz 
demonstrates that seventeenth-century semantics of usefulness were multifaceted and therefore transcended the concentration on technological advancement. Bacon is revealed as a false friend, whose ideas are closer to the research policy promises of basic research ("Grundlagenforschung") in the second half of the twentieth century, something the idea of technoscience is precisely meant to overcome (88). The Age of Enlightenment was also characterized by a broad meaning of usefulness, spanning individual and collective, material and immaterial, and immediate and longterm understandings (99).

Chapter Three is about the conceptions of natural science in the nineteenth century, the professionalization of science, and the emergence of the modern research university. Here, ideas of material utility in science first give way to the purpose of science for higher education (Bildung), with ideals of learnedness as characteristic for the natural scientist and as contributive to German culture and society. Pure science ("reine Wissenschaft") becomes the identity marker of the natural sciences, which emancipate themselves from philosophy and religion, and stress scientific progress and academic freedom as defining features. Moreover, in the second half of the century, the integrating symbol and formula to communicate the usefulness of natural sciences to society is the distinction between pure and applied science ("reine und angewandte Wissenschaft"). It provides a new order to the academic landscape in Germany, installing a clear hierarchy between natural and engineering sciences, while also allowing engineers to achieve academic status. Whereas pure science previously served to mark the border between science and engineering, it is now thought of as the basis for technological advancement, an idea which, despite current critique, proves to be one of the most enduring narratives of the relation between science and technology until today (217).

The tumultuous developments between the end of the German Empire and World War II are the subject of Chapter Four. Important changes here are the introduction of "Gemeinschaftsforschung" during the Weimar Republic as an answer to the increasing interest of industry in science. In contradistinction to the idea of pure science, it emphasized the material and economic utility for the war shattered nation (274). In this context, a semantic transition from science to research ("Forschung") occurs, displacing the notion of a hierarchy of knowledge types with the primacy of dynamic knowledge production processes as a collective endeavor with all its material foundations (291). Already begun during the 1920s, aligning research with social, economic, and political requirements reached its pinnacle during Nazi rule. Significantly, the regime's science policy is responsible for making the notion of basic research ("Grundlagenforschung"), together with "Zweckforschung," a crucial category in Germany (317). In contrast to historians, who have taken the concept as a sign of some independence of natural scientists from the Nazi's political goals, Schauz demonstrates that the metaphor of providing the "basis" ("Grundlagen") engrained into the category, although implying a certain degree of non-plannable long-term outcomes, nevertheless signified laying the foundations to technological uses, and thereby also to the regime's goals of self-reliance and war (340).

The metascientific discourses explored in Chapter Five were marked by the reconstruction of science in postwar West Germany and the harnessing of research for economic growth. Immediately after the war, university-centered research and 
nineteenth-century ideals were revived in order to contain the ambivalence of modern natural science (358). In front of the prevailing US ideology of basic research, "Grundlagenforschung" returns as a central identity marker for the natural sciences. However, this time the semantically flexible notion of providing the "basis" proves inclusive for diverse economic interests. In conjunction with applied research ("angewandte Forschung"), the basic research category slowly absorbs the attributes of purity ("Reinheitszuschreibungen") of the previous century, leading to a moral order of science, which compelled the engineering sciences to renegotiate their position within academia and science policy (379).

Wahrheit und Nützlichkeit is an impressive piece of socio-historical scholarship with a truly interdisciplinary scope. It reveals natural science to be a deeply human activity in which actors, despite the different framings, always found themselves confronted with the same problem of the openness and unpredictability of local research processes (400). With the meta-perspective on scientific identity-making, Schauz provides an invaluable contribution to disclosing the contingent and subjective underpinnings of the discourses that currently guide our work in science, technology, and innovation studies, and of the academic trends and political hypes informing decisions regarding research and funding.

Funding Open Access funding enabled and organized by Projekt DEAL.

Open Access This article is licensed under a Creative Commons Attribution 4.0 International License, which permits use, sharing, adaptation, distribution and reproduction in any medium or format, as long as you give appropriate credit to the original author(s) and the source, provide a link to the Creative Commons licence, and indicate if changes were made. The images or other third party material in this article are included in the article's Creative Commons licence, unless indicated otherwise in a credit line to the material. If material is not included in the article's Creative Commons licence and your intended use is not permitted by statutory regulation or exceeds the permitted use, you will need to obtain permission directly from the copyright holder. To view a copy of this licence, visit http://creativecommons.org/licen ses/by/4.0/.

Publisher's Note Springer Nature remains neutral with regard to jurisdictional claims in published maps and institutional affiliations. 